\title{
Stratified microbial communities are highly sensitive towards multiple combined global change factors, revealing antagonistic and synergistic effects
}

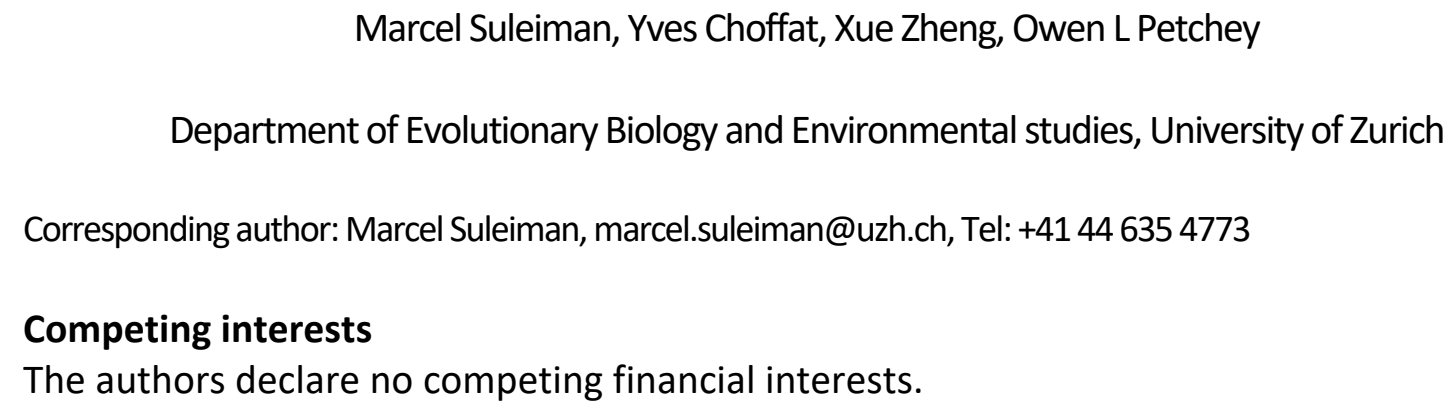

\section{Competing interests}

The authors declare no competing financial interests.

\section{Abstract}

Microbial communities in many ecosystems are facing a broad range of global change scenarios, resulting in microbial changes and possibly regime shifts with unknown ecological consequences. While the influence of single stressors is already described in numerous studies, the effects of multiple stressors working simultaneously are still poorly understood. In this study, we used 240 highly replicable oxic/anoxic aquatic lab micro-ecosystems to understand the influence of four stressors (fertilizer, glyphosate, metal pollution, antibiotics) in all possible combinations at three different temperatures $\left(20^{\circ} \mathrm{C}, 24^{\circ} \mathrm{C}\right.$, and $\left.28{ }^{\circ} \mathrm{C}\right)$ to shed light into consequences of multiple stressors on different levels of organization, ranging from species abundance to community and ecosystem parameters. Our data reveal that (i) combination of specific stressors can change the biological consequence and direction compared to single stressors in all levels of organisation (ii), effects of stressor combinations are modified by temperature, and (iii) that the number of stressors applied also lead to significant changes. In sum, our study confirmed the need of investigating multiple stressors working simultaneously across different ecological levels of organisation. 
bioRxiv preprint doi: https://doi.org/10.1101/2021.12.13.472339; this version posted December $22,2021$. The copyright holder for this preprint (which was not certified by peer review) is the author/funder, who has granted bioRxiv a license to display the preprint in perpetuity. It is made available under aCC-BY-NC-ND 4.0 International license.

29

30

31

32

\section{Introduction}

Microbial communities, as drivers of many ecosystems, must face increasing amounts and strengths of anthropogenic global change (Christensen et al. 2006; Jackson et al. 2016).

Confrontation with fertilizer (Suleiman et al. 2017) and metal pollution (Xu et al. 2018a), pesticides like glyphosate(Solomon and Thompson 2003; Relyea 2009), antibiotics (Xu et al. 2018b) and an ongoing temperature increase (Wu et al. 2011) force populations and whole ecosystems to develop in different ways compared to less or unaffected ones. For decades, many studies analysed and proved that even slight changes in environmental conditions can lead to large taxonomic and functional microbial change, and even to regime shifts, with potential (long term) consequences for biogeochemically cycles and ecological function of the affected habitat (Gruber 2011; Suleiman et al. 2021b).

While most studies so far focused on one global change stressor, recent studies (Christensen et al. 2006; Rillig et al. 2019; Suleiman et al. 2021a) indicated that multiple stressors applied simultaneously do not always show additive effects, which would be the sum of the individual stressors. Rather, they demonstrate that interaction effects can occur. These can be synergistic (combined effect greater than the sum of the effect of individual stressors) or antagonistic (combined effect less than the sum of the effect of individual stressors). Furthermore, it was shown, that not just the character of stressor, but also the number of factors combined plays a crucial role (Rillig et al. 2019). Nevertheless, the amount of studies testing three or more stressors for an experimental system in the lab remains very low (Rillig et al. 2019), which highlights the need of investigating combined effects on experimental ecosystems, and is a critical aspect of the research field of climate change microbiology (Hutchins et al. 2019). 

example, to assess all interactions, one needs a fully-factorial experimental design, and so experiments can very quickly become large. Regarding interpretation, it can be difficult to understand the meaning of interactions among more than three stressors, such that even if one would conduct a fully-factorial experiment, traditional methods for interpreting interactions (such as interaction plots) may be insufficient. Some studies have instead focused on the effect of variation in the number of stressors, and have applied only a subsample of all possible combinations (e.g. Brennan and Collins 2015; Rillig et al. 2019). across levels of ecological organization, from individuals to ecosystem (Galic et al. 2018). For example, Galic et al (2018) in a case study of a model of amphipod feeding behavior, showed that responses to multiple stressors at the individual level were not consistent with those at higher levels of organization. In their case-study, the nature of this inconsistency would lead to underestimation of effects at population and ecosystem levels if effects at the individual level were assumed to hold across levels of organisation. source of ecological surprises, i.e. if we assume additivity we can be surprised if there are interactions (Christensen et al 2006). Also, unless there are some generalities about interactions among drivers, we will never be able to predict the effect of a new (previously unobserved) combination of drivers, so interactions will also then be a surprise (Christensen et al 2006). Hence, we and others (e.g. Simmons et al 2021, Rillig et al 2018) are interested in discovering if there are any general patterns that will allow us to predict the effects of 
patterns in the effects of combinations of environmental drivers. For example, is the relationship between a biological variable and the number of drivers dependent on the level of ecological organization of the biological variable. And do the strength and nature of the interaction effects vary with level of ecological organization. biotic interactions (Singh et al. 2009), with and within specific functional microbial groups

84 (Bush et al. 2017; Richardson et al. 2018). Recently, previous work indicated that these networks are sensitive to environmental change (Christensen et al. 2006; Shade et al. 2011, 2012; Suleiman et al. 2021b, a), identifying these habitats as appropriate systems for study and understanding influences of global changes.

In this work, we applied four different global change stressors (fertilizer, glyphosate, metal pollution, antibiotics, and temperature) in all combinations possible with increasing temperature $\left(20^{\circ} \mathrm{C}, 24^{\circ} \mathrm{C}\right.$, and $\left.28^{\circ} \mathrm{C}\right)$, on a recently developed and highly replicable stratified aquatic microbial lab system, resulting in a total number of 240 analysed experimental microecosystems. Our experiment includes the analysis of several abiotic (oxygen, total nitrogen, total organic carbon, $\mathrm{pH}$ ) and biotic variables (diversity richness, microbial community composition, genera abundances), since recent studies have shown that various levels of ecosystems can be affected (Weithoff et al. 2000; Shade et al. 2011, 2012; Suleiman et al. 2021b). We hypothesize that (i) depending on the combinations of stressors the ecosystems will be driven in different directions and (ii) increasing temperatures can change the influence of combined stressors (iii) increasing number of stressors goes along with significant effects. 


\section{Material and methods}

102

\section{Experimental set up}

104

Incubation of stratified microbial communities was performed in micro-ecosystems consisting of standard glass test tubes ( $4 \mathrm{~mL}$ volume). These test tubes were closed with plastic lids, with a small whole $(0.5 \mathrm{~mm})$ that allowed gas exchange between the headspace and the atmosphere. Each micro-ecosystem consisted of sediment and water samples taken in May from a small pond in Zurich, Switzerland $\left(47^{\circ} 23^{\prime} 51.2^{\prime \prime} \mathrm{N} 8^{\circ} 32^{\prime} 33.3^{\prime \prime} \mathrm{E}\right.$, the temperature of 19 ${ }^{\circ} \mathrm{C}, \mathrm{pH}$ of 7) at a depth of $25 \mathrm{~cm}$. Sediment was homogenized (30 min mixing) and subsequently supplemented with sterile $0.25 \%$ crystalline cellulose, $0.25 \%$ methyl-cellulose, $0.5 \% \mathrm{CaSO}_{4}$, $0.1 \% \mathrm{CaCO}_{3}$, and $0.005 \% \mathrm{NH}_{4} \mathrm{H}_{2} \mathrm{PO}_{4}$. Glass tubes were filled with a $3 \mathrm{~mm}$ layer of supplemented sediment and covered with $3.5 \mathrm{~mL}$ pond water (with $0.005 \% \mathrm{NH}_{4} \mathrm{H}_{2} \mathrm{PO}_{4}$ ), resulting in $500 \mu \mathrm{L}$ headspace. Microecosystems were incubated at room temperature for 2 hours to let sediment settle, before the different treatments were applied. Incubation took place for 23 days (about three and a half weeks) at $20^{\circ} \mathrm{C}, 24^{\circ} \mathrm{C}$ and $28^{\circ} \mathrm{C}$, respectively.

\section{Multiple stressor treatments}

In this work, there were two levels of four stressors, namely $\mathrm{NH}_{4} \mathrm{H}_{2} \mathrm{PO}_{4}$-fertilizer $(\mathrm{F})$,

120 Glyphosate (G), metal pollution (M) and antibiotics (A). Furthermore, control microecosystems (C) were used without application of any stressors. Additionally, the experiment was carried out at $20^{\circ} \mathrm{C}, 24^{\circ} \mathrm{C}$ and $28^{\circ} \mathrm{C}$ under a dark-light cycle of $8: 16 \mathrm{~h}$, respectively. The temperature treatment and four stressor treatments were applied in a fully-factorial design.

124 Five replicates per treatment combination resulted in 240 micro-ecosystems, according to the following design: 
For the stressor treatments, the following chemical compounds were added to the microstudy (Suleiman et al., 2021)

- Glyphosate in final concentration of $0.0001 \%(G)$ like used in a recent study of (da Costa et al. 2021)

- Trace element solution SL-10 final concentration 10x higher than recommended for metal pollution (M)

141 Stressors were applied to the micro-ecosystems only on day 0; there were no further press or pulse perturbations.

\section{Sampling and full length 16S rRNA sequencing}

After incubation for 23 days, the whole micro-ecosystem was centrifuged for $5 \mathrm{~min}$ at 10.000 rpm (sediment and water column together). DNA was extracted using ZymoBIOMICS DNA 
PCR products were visualized on an $1 \%(\mathrm{w} / \mathrm{v})$ agarose gel and were pooled for sequencing in equal concentrations. PCR product pools were purified using AMPure ${ }^{\circledR} \mathrm{PB}$ beads (PacBio). Sequencing was performed at the Functional Genomic Center Zürich, Switzerland, and performed using SMRT Technology (PacBio) as reported previously (on three SMRT chips). Sequencing data quality were checked using the PacBio SMRT Link software.

\section{Bioinformatics}

Sequencing data were filtered based on primer sequences, length (1300-1600 bp), quality, error rates and chimeras usind dada2 (Callahan et al. 2016). The final sequence table was aligned using SILVA ribosomal RNA database (Quast et al. 2012), using version 138 (nonredundant dataset 99). A phyloseq object was created using the phyloseq package (McMurdie and Holmes 2013), consisting of amplicon sequence variant (ASV) table, taxonomy table and sample data. For further analysis, the R packages phyloseq (McMurdie and Holmes 2013) and vegan (Oksanen et al. 2019) were used. In order to compare the effects of the multiple stressors, we analysed various response variables, namely community composition based on NMDS1, NMDS2, Shannon richness, oxygen, TN, TOC, and abundances of specific genera and functional groups. Microbial community composition was quantified using NMDS (non-metric multidimensional scaling) based on Bray-Curtis scores with the metaMDS function of the

171 vegan R package (Oksanen et al. 2019), with three dimensions used $(k=3$, try=100). Shannon

172 richness was calculated using phyloseq package (McMurdie and Holmes 2013). Functional

173 groups were constructed by filtering for cyanobacterial and sulfur-related species, which 174 resulted in a reduced dataset consisting of members of the order of Cyanobacteriales, 175 Chromatiales, Synechococcales, Chlorobiales, Leptolyngbyales, Desulfobulbales, 
bioRxiv preprint doi: https://doi.org/10.1101/2021.12.13.472339; this version posted December $22,2021$. The copyright holder for this preprint (which was not certified by peer review) is the author/funder, who has granted bioRxiv a license to display the preprint in perpetuity. It is made available under aCC-BY-NC-ND 4.0 International license.

176

177

178

180

181

182

183

184

185

186

187

188

189

190

191

192

193

194

195

196

197

198

199

200

Desulfovibrionales, Limnotrichales and Campylobacterales. Detailed scripts and a phyloseq with all sequences are available on github (https://github.com/Marcel2907/multiplestressor).

\section{Measurement of abiotic factors}

Oxygen concentration was measured $1.5 \mathrm{~cm}$ below the water/air interphase using an oxygen dipping probe (PreSens, Germany) at the last day of incubation. $\mathrm{pH}$ was measured in the supernatant of the centrifuged micro-ecosystem, as well as total nitrogen (TN) and total organic carbon using a TOC analyser.

\section{Results}

We first results about the microbial community and genera abundances of the 240 microecosystems (Fig. 1), then, the impact of stressor combination as well as number of stressors were calculated for diversity richness (Shannon), community structure (NMDS1), community structure of a subpopulation, as well oxygen and $\mathrm{pH}$ (Fig. 2). Additional abiotic and biotic variables were investigated (NMDS2, total nitrogen, total carbon) and can be find in detail in the Supplementary Fig. 3. The summary results of all variables (species, community, ecosystem) analysed based on the impact of stressor combination can be found in Fig. 3, and the influence of number of stressors in Fig. 4.

In total, 20’319 unique ASVs were identified after running the dada2 pipeline. After filtering to retain ASVs that appear at least in a rel. abundance of $0.1 \%$ in at least one sample, the total number of reads decreased to 5830 taxa. The control micro-ecosystems consisted of mainly cyanobacteria (e.g. Phormidaceae) and phototrophic sulfur bacteria (specially Chromatiaceae) (Fig. $1 \mathrm{a}+$ b, Supplementary Fig. 1). Depending on the stressor combination and temperature, the microbial communities and genera abundances showed strong 
differences compared to the controls. Micro-ecosystems facing stressors of glyphosate and metal pollution, as a single stressor or in combination, were still dominated by members of Phormidiaceae and Chromatiaceae like the controls, but in all remaining treatments the abundance of members of these families was strongly decreased (Supplementary Fig. 1).

205

Also on genus level, we observed shifts in microbial composition depending on stressor combination and temperature (Fig. 1 b). The cyanobacterial genus Tychonema is highly abundant in metal pollution treatment, and with increasing temperature also in glyphosate + metal pollution treatments $\left(20 \%\right.$ at $28^{\circ} \mathrm{C}, 7 \%$ at $\left.20^{\circ} \mathrm{C}\right)$. Chromatium, in contrast, appears in several treatments and reached highest rel. abundance at $20{ }^{\circ} \mathrm{C}$ when confronted with $\mathrm{G}: \mathrm{M}$

211 (20\%), but vanished with increasing temperature in all treatments $(<5 \%)$. Statistical analysis

212 of the relative abundance dependent on stressor combinations and temperature were

213 performed on genus level for Tychonema, Sulfuricurvum and Chromatium, as representative

214 species for Cyanobacteria and sulfur-depending bacteria (Fig. 3). Statistical analysis confirmed

215 significant changes of relative species abundance depending on stressors, their combination and the temperature, but also depended on number of stressors applied (Fig. 4). 


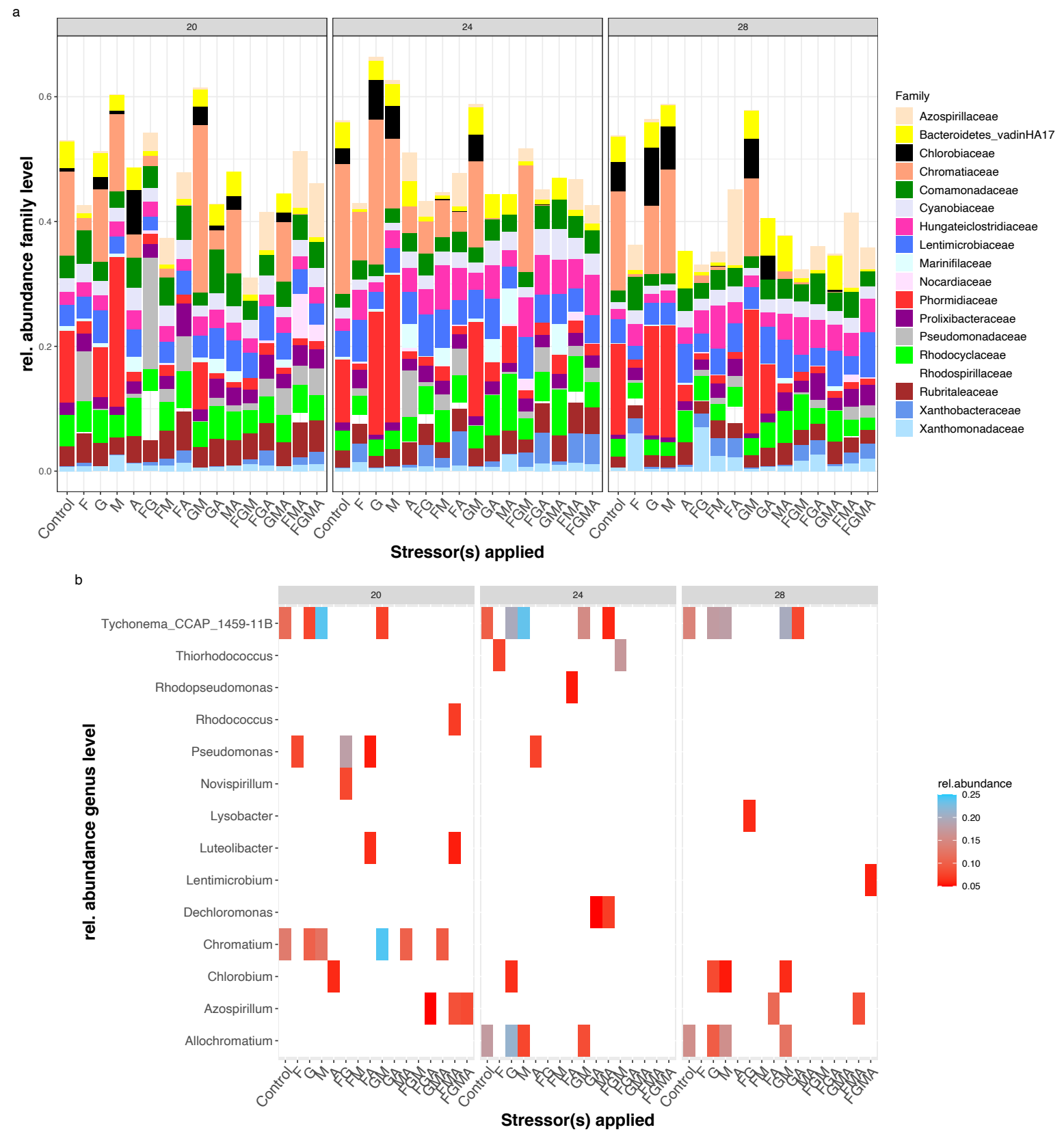

Fig. 1 Overview of microbial communities and genera abundance depending on temperature and stressors combined. (a) Microbial community composition (mean per 5 replicates) on family level. Taxa with rel. abundance $>5 \%$ shown. (b) Relative abundance of specific genera with rel. abundance $>5 \%$ for each stressor combination at each of the three temperatures. White color represents a relative abundance $<5 \%$.

ASV diversity of the micro-ecosystems changed depending on the combination of stressors (Fig. 2a+b), resulting in Shannon index values between 3 and 7, with the majority of samples between 5 and 6 , indicating a high diversity in most of the micro-ecosystems. Several 
bioRxiv preprint doi: https://doi.org/10.1101/2021.12.13.472339; this version posted December 22,2021 . The copyright holder for this preprint (which was not certified by peer review) is the author/funder, who has granted bioRxiv a license to display the preprint in perpetuity. It is made available under aCC-BY-NC-ND 4.0 International license.

increase ( $p$ 1.41e-03), fertilizer ( $p$ 9.32e-05), antibiotics ( $p$ 7.85e-07), as well as combination of fertilizer+antibiotics ( $p$ 3.82e-05) and fertilizer+antibiotics+glyphosate (p 3.02e-02) (Fig. 2a). All listed significant stressor combinations had a positive effect on diversity, except of temperature increase to $28{ }^{\circ} \mathrm{C}$ and fertilizer:antibiotic treatment (Fig. 3). Interestingly, the negative effect of fertilizer:antibiotic was reversed to a positive effect again by adding glyphosate, while the treatment of glyphosate alone had no impact (Fig. 2a, Fig. 3). When analysing the effect of number of stressors and temperature increase on diversity, just temperature was identified to have a significant effect, but the number of stressors had no impact (Fig. 2b, Fig. 4). using NMDS, and fertilizer was identified as a key stressor for shifting microbial communities (NMDS1 p 5.11e-77) (Fig. 2b+c, Supplementary Figure 2). Numerous stressor combinations showed significant differences for NMDS score 1 and NMDS score 2 compared to the controls (Fig. 2c for NMDS1, Supplementary Fig. 3 for NMDS2, Fig. 3 for both), ranging from single to four-factorial combined stressors. Different impact directions (positive or negative score change) of the estimates can be identified depending on the stressor combinations (Fig. 2c, Fig. 3). The three-way interaction of fertilizer+antibiotics+temperature on NMDS1 score is a good example how combination of stressors can change the impact direction (Fig. 5): When no fertilizer was present, the NMDS1 score was negative, while in presence of fertilizer, the NMDS1 score was positive. The combination of antibiotics and temperature changed additionally the magnitude of the NMDS1 score. NMDS1 and NMDS2 scores were affected by number of stressors ( $p$ 5.07e-17 and $p$ 3.96e-04, respectivley), but not by total number of stressors interacting with temperature (Fig. 2d, Fig. 4). The number of stressors did also affect 
Analysis of the subset of cyanobacteria, phototrophic sulfur bacteria and sulfate-

255

256

257

258

259

260

261

262

263

264

265

266

267

268

269

270

271

272

273

274

275

276

277 reducing bacteria confirmed the trends observed for NMDS of the whole data set (Fig. 2e for NMDS1, Supplementary Fig. 3 for NMDS2, Fig. 3 for both), but showed slight differences on three-factorial and four-factorial stressor combinations.

Oxygen concentration was highly dependent on the stressor combinations used, and various strong effects were identified (Fig. $2 \mathrm{~g}$ ), both positive and negative in direction. All stressors combined had a negative effect on oxygen concentration ( $p$ 4.04e-02, nonstandardised estimate - 6.1). The number of stressors applied had a strong effect on the oxygen concentration ( $\mathrm{p} 3.02 \mathrm{e}-05)$, as well as temperature ( $\mathrm{p} 4.7 \mathrm{e}-08)$ and the interaction of temperature + number of factors ( $p$ 0.04) (Fig. 2h, Fig. 4).

The $\mathrm{pH}$ of the micro-ecosystems was influenced by numerous treatment combinations, but the strongest influences was identified as fertilizer addition, which decreased the $\mathrm{pH}$ from 8.5 to 6.5 ( $\mathrm{p} 4.76 \mathrm{e}-118$ ). Stressor combinations that include fertilizer addition had lower magnitude though were of the same sign (Fig. 3).Number of stressors had a negative effect on $\mathrm{pH}$, though this was mostly due to the strong influence of fertilizer and its greater probability of occurrence in treatment combinations with more stressors applied (Fig. 4).

Effects on total nitrogen were driven by addition of fertilizer ( $p$ 1.58e-65), and this was not changed by addition of other stressors (Fig. 3, Supplementary Fig. 3). Furthermore, number of stressors was highly affecting the total nitrogen concentration ( $p$ 4.09e-12), which again can be explained by fertilizer addition alone. Total carbon concentration was significantly negative affected by fertilizer ( $p$ 0.006), metal pollution ( $p$ 0.025) and temperature (p 0.029) (Fig. 3, Supplementary Fig. 3). 
bioRxiv preprint doi: https://doi.org/10.1101/2021.12.13.472339; this version posted December 22, 2021. The copyright holder for this preprint (which was not certified by peer review) is the author/funder, who has granted bioRxiv a license to display the preprint in perpetuity. It is made available under aCC-BY-NC-ND 4.0 International license.
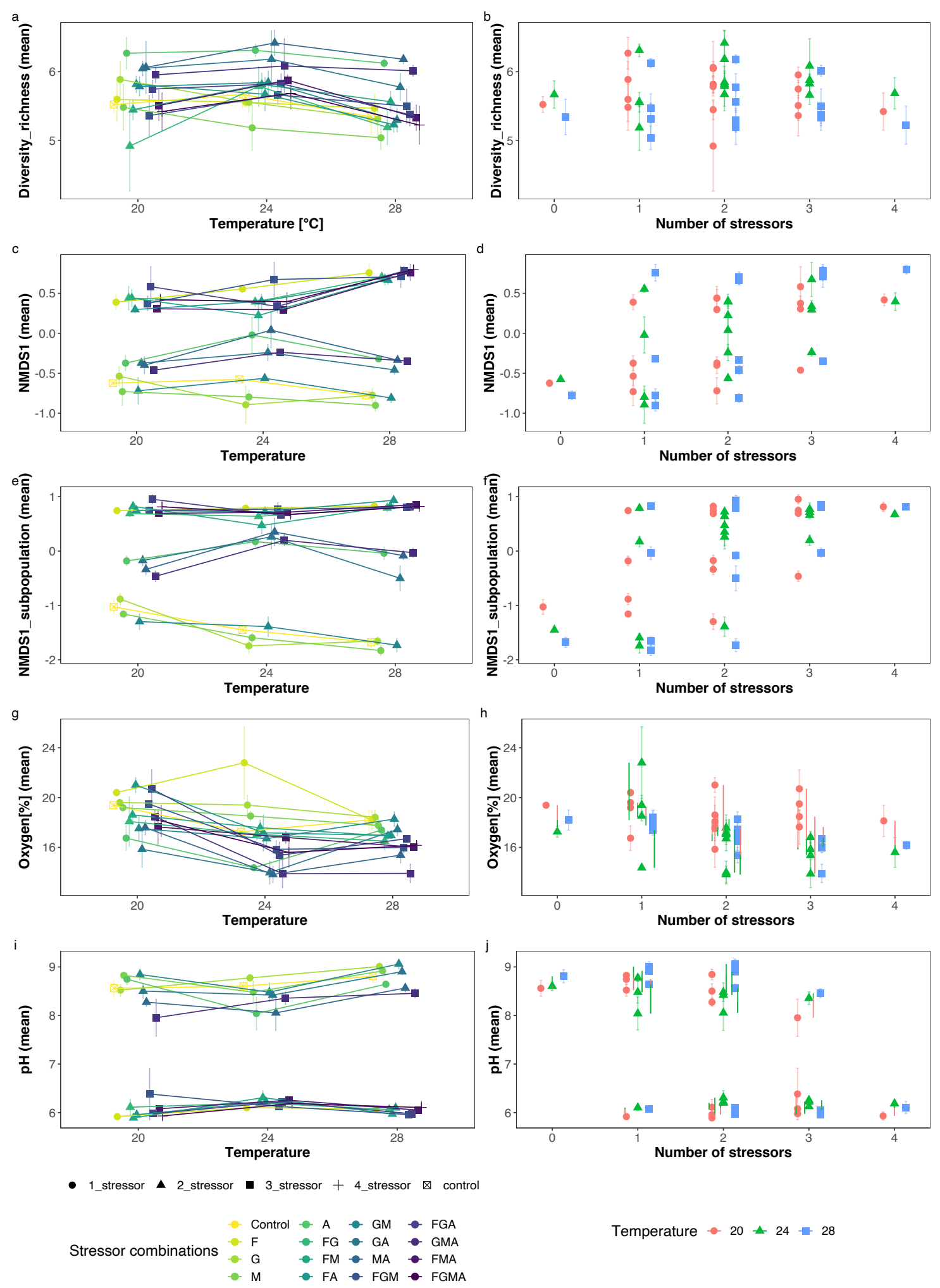

Fig. 2 Effects of stressor combination and number of stressors on temperature applied for microbial community and ecosystem variables. Shannon diversity index in dependence on (a) temperature and stressor combination and (b) temperature and number of stressors. NMDS1 scores in dependence on (c) temperature and stressor combination and (d) temperature and number of stressors. NMDS1_subpopulation scores dependence on (e) temperature and stressor combination and (f) temperature and number of stressors. Oxygen concentration in dependence on (g) temperature and stressor combination and (h) temperature and number of stressors. $\mathrm{pH}$ scores in dependence on (i) temperature and stressor combination and (j) temperature and number of stressors. Standard errors are shown ( $n=5$ replicates). 
bioRxiv preprint doi: https://doi.org/10.1101/2021.12.13.472339; this version posted December 22, 2021. The copyright holder for this preprint (which was not certified by peer review) is the author/funder, who has granted bioRxiv a license to display the preprint in perpetuity. It is made available under aCC-BY-NC-ND 4.0 International license.

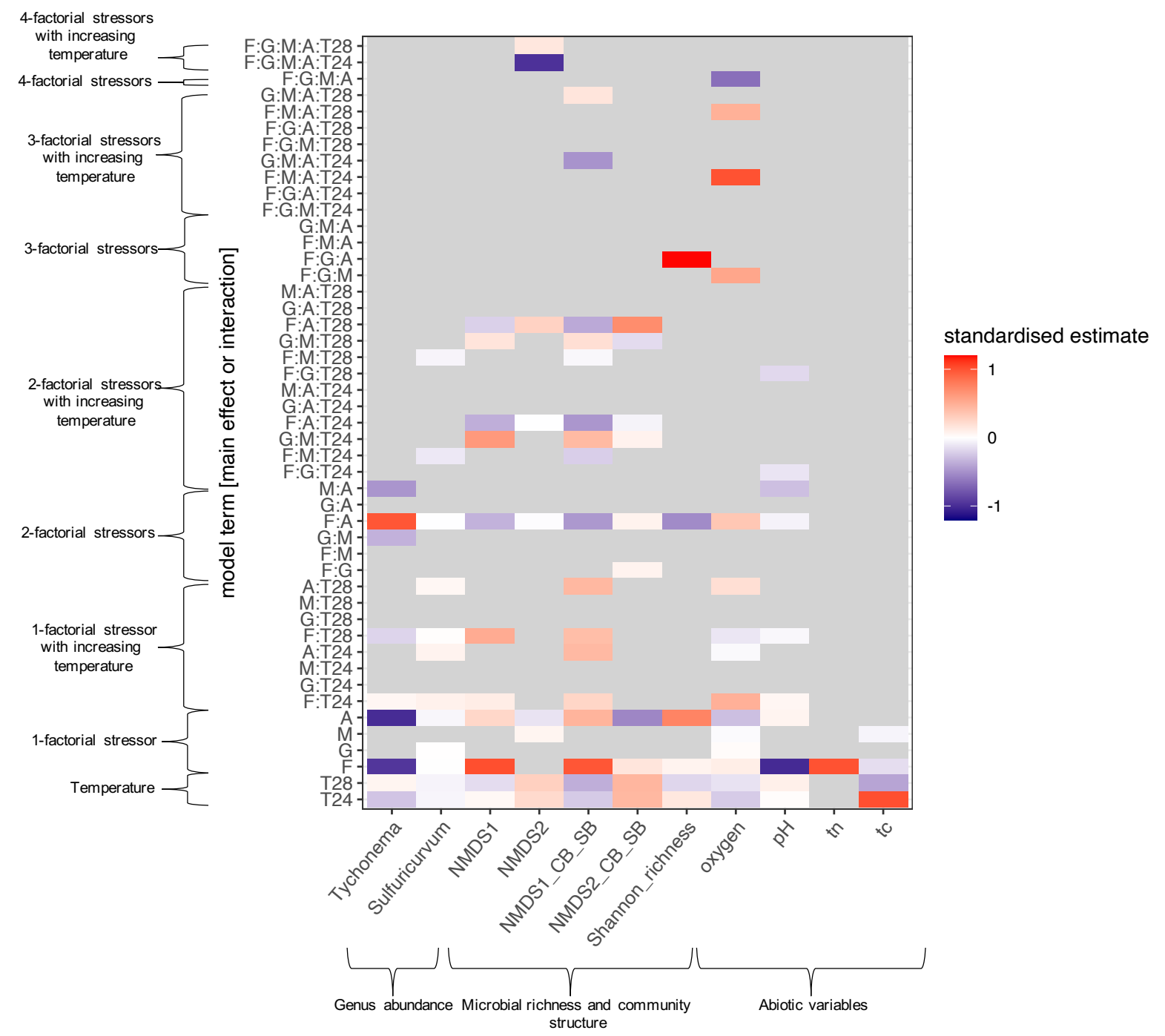

Fig. 3 Summary of statistical analyses of all variables analysed.

We analysed how 12 variables (grouped by genus appearance, microbial richness and community structure and abiotic factors) are affected by four factors applied in all combinations possible and additionally at three different temperatures. Coefficient intervals ( $t$-test) are shown for significant affected stressor combination (F-test $p$-value $<0.05$ ). Color scheme illustrates the direction of the influence by the stressor (based on estimate positive or negative, estimates of each variable were standardized by dividing by highest estimate value. Grey: not significant based on $f$-test ( $p$ value $>0.05$ ). $t n=t$ total nitrogen, $\mathrm{tc}=$ total carbon. 
bioRxiv preprint doi: https://doi.org/10.1101/2021.12.13.472339; this version posted December 22, 2021. The copyright holder for this preprint (which was not certified by peer review) is the author/funder, who has granted bioRxiv a license to display the preprint in perpetuity. It is made available under aCC-BY-NC-ND 4.0 International license.

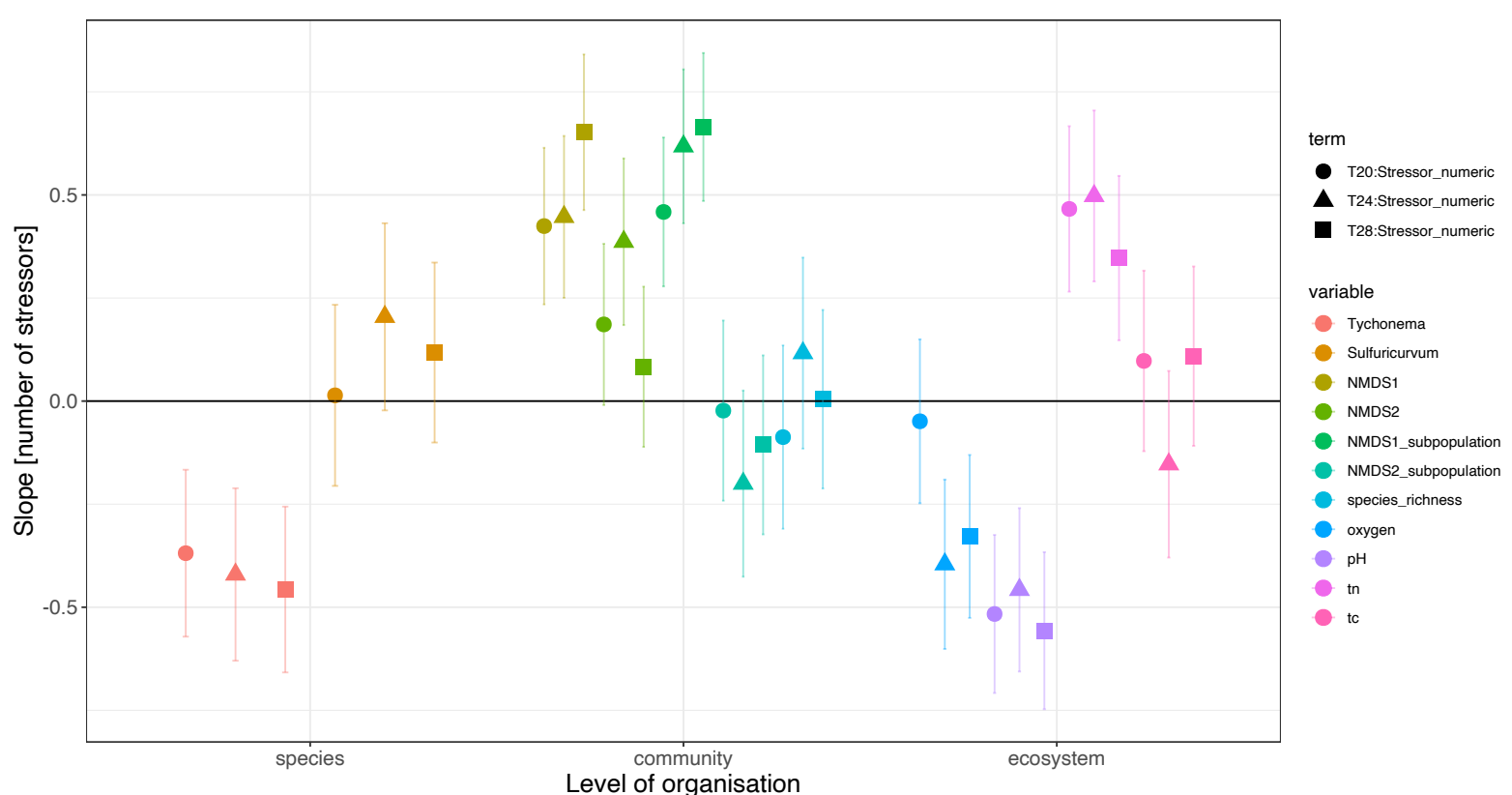

Fig. 4 Slope of effect of number of stressors over temperature for all level or organisation (species, community, ecosystem). $95 \%$ confidence intervals are shown. tn=total nitrogen, tc=total carbon.

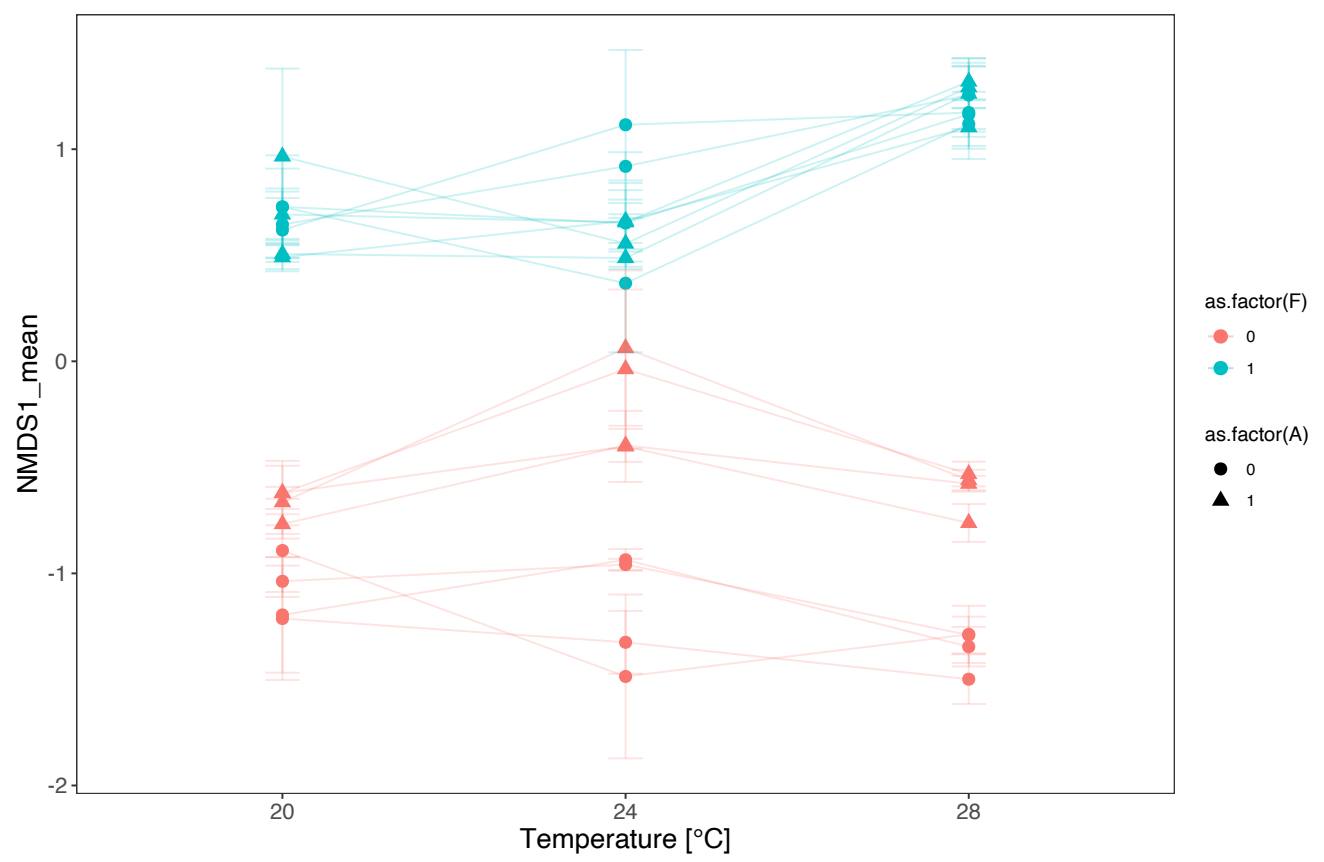

Fig. 5 Visualization of the significant stressor (interactions) of temperature, fertilizer and antibiotics on NMDS1. NMDS1 is affected by the presence of fertilizer, the presence of antibiotics and temperature, but also by the interactions of fertilizerantibiotics and Fertilizer-antibiotics-temperature. 
bioRxiv preprint doi: https://doi.org/10.1101/2021.12.13.472339; this version posted December 22, 2021. The copyright holder for this preprint (which was not certified by peer review) is the author/funder, who has granted bioRxiv a license to display the preprint in perpetuity. It is made available under aCC-BY-NC-ND 4.0 International license.

310

311

312

313

314

315

316

317

318

319

320

321

322

323

324

325

326

327

329

330

331

332

333

\section{Discussion}

Our study revealed strong evidence of effects of the combination and the total number of stressor on taxa abundances, community composition, and ecosystem properties, and therefore confirmed recent findings that multiple stressors are highly important to study (Rillig et al. 2019). The addition of a stressor, and/or temperature increase, could change the biological consequence of already applied stressors, even when the added stressor applied alone had no effect (Fig. 3). We observed three trends here: The addition of a further stressor can increase (e.g. F:A:T28), decrease (e.g. F:T28) or turn the whole direction of stressors which were already applied (e.g. F:A on Tychonema abundance, Fig. 6). This demonstrates clearly the need of analysing multiple stressors in all possible combinations. Furthermore, our study also confirmed that the number of stressors applied alone can have an effect on microbial communities and thereby provides some hope that number of stressors can be used as a predictor, though it is clear that individual stressor effects can greatly contributed to the effect of number of stressors (Rillig et al. 2019). The effect of number of stressors can be negatively (e.g. Tychonema abundance) or positively (e.g. total nitrogen), which highlights again the need of analysing various ecological response variables of species, microbial communities and the whole ecosystem.

While fertilizer, metal pollution and antibiotics had numerous effects when applied as a single stressor, glyphosate did not show this trend. This finding is probably concentration dependent and should be regarded with caution. Nevertheless, it is even more interesting that when adding glyphosate to more stressors it can have an effect (see e.g. diversity richness). Strong interactions were detected for antibiotics and fertilizer, and interestingly, these stressors revealed in combination different biological consequences compared to 


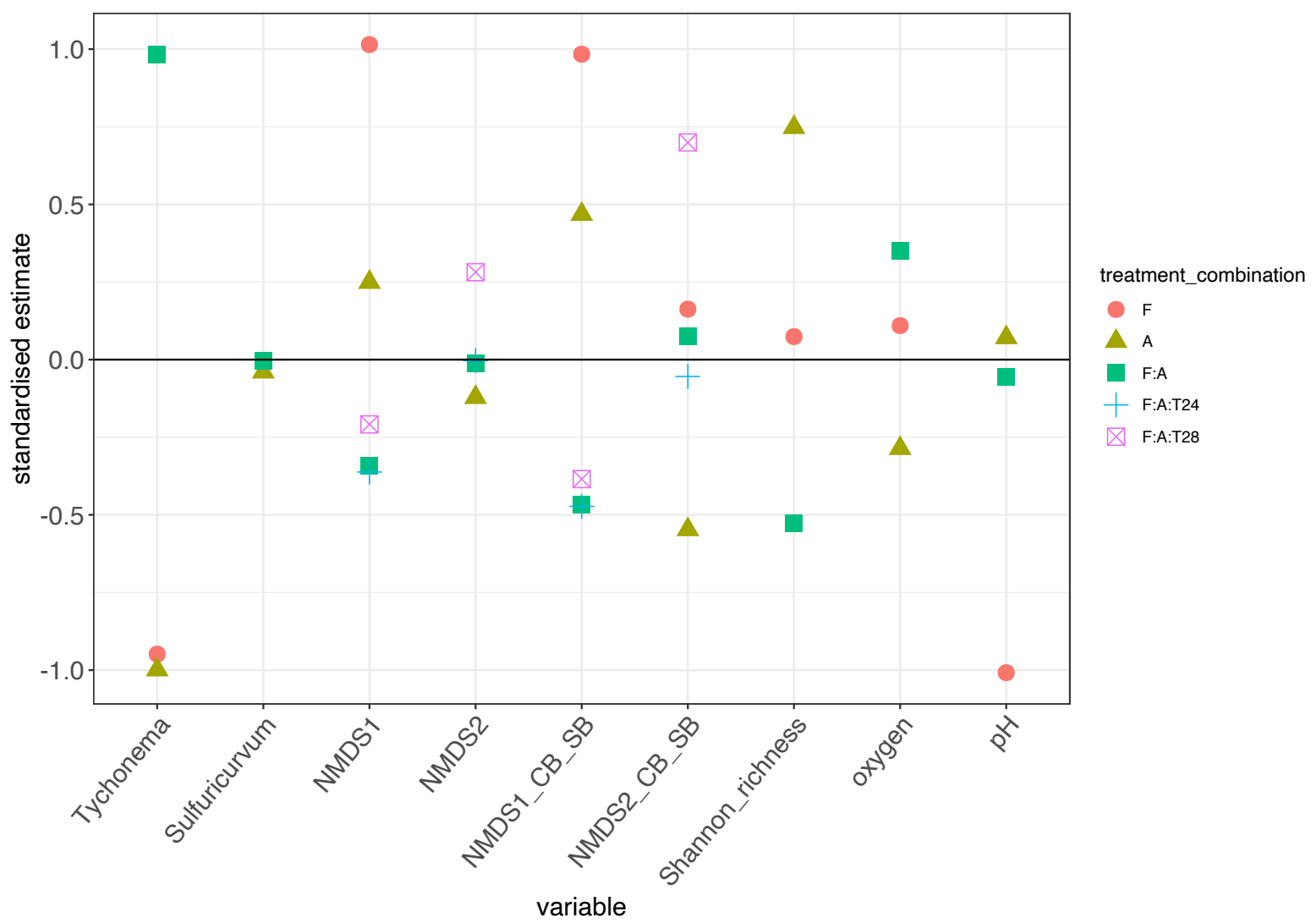

Fig. 6 Effects of fertilizer, antibiotics and their combination at $20^{\circ} \mathrm{C}$ and elevated temperature on species, microbial carbon are not listed in this figure because they were not significantly affected by F, A, and F:A. on-going global warming. An increase of temperature can lead to new interactions among stressor combinations ( $\mathrm{F}: \mathrm{A}$ with increasing temperature led again to significant affected variables) or can lead to significant effects that were not observed at $20{ }^{\circ} \mathrm{C}$ (G:M, G:M:24 and $\mathrm{G}: \mathrm{M}: 28$ for NMDS1). 
bioRxiv preprint doi: https://doi.org/10.1101/2021.12.13.472339; this version posted December 22,2021 . The copyright holder for this preprint (which was not certified by peer review) is the author/funder, who has granted bioRxiv a license to display the preprint in perpetuity. It is made available under aCC-BY-NC-ND 4.0 International license.

individuals can be affected differently compared to abiotic factors of the ecosystem or the microbial community composition. Therefore, our study is in line with the findings of Galic et al. (2018) who reported already differences of the influence of multiple stressors across levels of organisation. Interestingly, in our study, some treatment combinations, like fertilizer and antibiotics working simultaneously, showed significant influence across most of the different levels of organisation (except total nitrogen and total carbon).

Stressors and how they are affecting ecosystems and communities are concentrationdependent. In this study, we did used only two levels of stressor concentration and added the stressor in a single pulse treatment. More information about specific concentration thresholds and press disturbances are important to study and may clarify some observed trends, as well as the timing of the stressor applied. In addition, responses of functional aspects of the aquatic microbial communities should be investigated in future studies, which could shed light into activated and deactivated pathways and enzymes used in microbial communities to react to changing environmental conditions. (species, microbial community, ecosystem) should be analysed due to its variation of 
402

403

404

405

406

407

408

409

410

411

412

413

414

415

416

417

418

419

420

\section{Literature}

Brennan G, Collins S (2015) Growth responses of a green alga to multiple environmental drivers. Nat Clim Chang 5:892-897. https://doi.org/10.1038/nclimate2682

Bush T, Diao M, Allen RJ, et al (2017) Oxic-Anoxic regime shifts mediated by feedbacks between biogeochemical processes and microbial community dynamics. Nat Commun 8:. https://doi.org/10.1038/s41467-017-00912-x

Callahan BJ, McMurdie PJ, Rosen MJ, et al (2016) DADA2: High-resolution sample inference from Illumina amplicon data. Nat Methods 13:581-583. https://doi.org/10.1038/nmeth.3869

Christensen MR, Graham MD, Vinebrooke RD, et al (2006) Multiple anthropogenic stressors cause ecological surprises in boreal lakes. Glob Chang Biol 12:2316-2322. https://doi.org/https://doi.org/10.1111/j.1365-2486.2006.01257.x

da Costa N, Fugère V, Hébert M-P, et al (2021) Resistance, resilience, and functional redundancy of freshwater bacterioplankton communities facing a gradient of agricultural stressors in a mesocosm experiment. Mol Ecol 30:4771-4788. https://doi.org/https://doi.org/10.1111/mec.16100

Davis J, Sim L, Chambers J (2010) Multiple stressors and regime shifts in shallow aquatic ecosystems in antipodean landscapes. Freshw Biol 55:5-18. https://doi.org/https://doi.org/10.1111/j.1365-2427.2009.02376.x

Faust K, Raes J (2012) Microbial interactions: from networks to models. Nat Rev Microbiol 10:538-550. https://doi.org/10.1038/nrmicro2832

Galic N, Sullivan LL, Grimm V, Forbes VE (2018) When things don't add up: quantifying impacts of multiple stressors from individual metabolism to ecosystem processing. Ecol Lett 21:568-577. https://doi.org/https://doi.org/10.1111/ele.12923

Gruber N (2011) Warming up, turning sour, losing breath: ocean biogeochemistry under global change. Philos Trans R Soc A Math Phys Eng Sci 369:1980-1996. https://doi.org/10.1098/rsta.2011.0003

Hutchins DA, Jansson JK, Remais J V, et al (2019) Climate change microbiology - problems and perspectives. Nat Rev Microbiol 17:391-396. https://doi.org/10.1038/s41579-019$\underline{0178-5}$

Jackson MC, Loewen CJG, Vinebrooke RD, Chimimba CT (2016) Net effects of multiple stressors in freshwater ecosystems: a meta-analysis. Glob Chang Biol 22:180-189. https://doi.org/https://doi.org/10.1111/gcb.13028 
421

422

423

424

425

426

427

428

429

430

431

432

433

434

435

436

437

438

439

440

441

442

443

444

445

446

447

448

449

450

451

452

453

454

455

456

457

458

459

460

461

462

463

464

465

466

467

McMurdie PJ, Holmes S (2013) Phyloseq: An R Package for Reproducible Interactive Analysis and Graphics of Microbiome Census Data. PLoS One 8:.

https://doi.org/10.1371/journal.pone.0061217

Oksanen J, Blanchet FG, Friendly M, et al (2019) Package "vegan" Title Community Ecology Package. Community Ecol Packag 2:1-297

Quast C, Pruesse E, Yilmaz P, et al (2012) The SILVA ribosomal RNA gene database project: improved data processing and web-based tools. Nucleic Acids Res 41:D590-D596. https://doi.org/10.1093/nar/gks1219

Relyea RA (2009) A cocktail of contaminants: How mixtures of pesticides at low concentrations affect aquatic communities. Oecologia 159:363-376. https://doi.org/10.1007/s00442-008-1213-9

Richardson J, Miller C, Maberly SC, et al (2018) Effects of multiple stressors on cyanobacteria abundance vary with lake type. Glob Chang Biol 24:5044-5055. https://doi.org/https://doi.org/10.1111/gcb.14396

Rillig MC, Ryo M, Lehmann A, et al (2019) The role of multiple global change factors in driving soil functions and microbial biodiversity. Science (80- ) 366:886-890. https://doi.org/10.1126/science.aay2832

Shade A, Read JS, Welkie DG, et al (2011) Resistance, resilience and recovery: Aquatic bacterial dynamics after water column disturbance. Environ Microbiol 13:2752-2767. https://doi.org/10.1111/j.1462-2920.2011.02546.x

Shade A, Read JS, Youngblut ND, et al (2012) Lake microbial communities are resilient after a whole-ecosystem disturbancefile:///Users/marcel/Downloads/10.1007_PL00008896citation.ris. ISME J 6:2153-2167. https://doi.org/10.1038/ismej.2012.56

Singh BK, Dawson LA, Macdonald CA, Buckland SM (2009) Impact of biotic and abiotic interaction on soil microbial communities and functions: A field study. Appl Soil Ecol 41:239-248. https://doi.org/https://doi.org/10.1016/i.apsoil.2008.10.003

Solomon KR, Thompson DG (2003) Ecological risk assessment for aquatic organisms from over-water uses of glyphosate. J Toxicol Environ Heal - Part B Crit Rev 6:289-324. https://doi.org/10.1080/10937400306468

Suleiman M, Brandt FB, Brenzinger K, et al (2017) Potential N2O Emissions from the Tanks of Bromeliads Suggest an Additional Source of N2O in the Neotropics. Microb Ecol 73:751-754. https://doi.org/10.1007/s00248-016-0903-9

Suleiman M, Choffat Y, Daugaard U, Petchey OL (2021a) Large and interacting effects of temperature and nutrient addition on stratified microbial ecosystems in a small, replicated, and liquid-dominated Winogradsky column approach. Microbiologyopen 10:e1189. https://doi.org/https://doi.org/10.1002/mbo3.1189 
Suleiman M, Pennekamp F, Choffat Y, Petchey OL (2021b) Contrasting resistance and resilience to light variation of the coupled oxic and anoxic components of an experimental microbial ecosystem. bioRxiv. https://doi.org/10.1101/2021.08.13.456201

Weithoff G, Lorke A, Walz N (2000) Effects of water-column mixing on bacteria, phytoplankton, and rotifers under different levels of herbivory in a shallow eutrophic lake. Oecologia 125:91-100. https://doi.org/10.1007/PL00008896

Wu Z, Dijkstra P, Koch GW, et al (2011) Responses of terrestrial ecosystems to temperature and precipitation change: a meta-analysis of experimental manipulation. Glob Chang Biol 17:927-942. https://doi.org/https://doi.org/10.1111/j.1365-2486.2010.02302.x

Xu J, Chen Y, Zheng L, et al (2018a) Assessment of heavy metal pollution in the sediment of the main tributaries of Dongting Lake, China. Water (Switzerland) 10:1-16. https://doi.org/10.3390/w10081060

Xu Z, Li T, Bi J, Wang C (2018b) Spatiotemporal heterogeneity of antibiotic pollution and ecological risk assessment in Taihu Lake Basin, China. Sci Total Environ 643:12-20. https://doi.org/10.1016/j.scitotenv.2018.06.175

\section{Acknowledgements}

MS was funded by Forschungskredit of the UZH (FK-20-125). OLP was supported by the University of Zurich Research Priority Programs in Global Change and Biodiversity. OLP and CZ were supported by Swiss National Science Foundation (Project 310030_188431). We thank the Predictive Ecology group and especially Uriah Daugaard for valuable input and data analysis support. We thank the Functional Genomic Center Zurich for sequencing efforts.

\section{Author contribution}

OLP and MS planned the experimental set-up. MS performed all experiments in the lab. MS performed the up- and downstream bioinformatics. MS and OLP performed the data analysis. YC provided technical support and performed the TOC analysis. XZ performed the DNA extractions and provided technical support. OLP and MS drafted the manuscript. All authors confirmed the final version of the manuscript. 
bioRxiv preprint doi: https://doi.org/10.1101/2021.12.13.472339; this version posted December 22, 2021. The copyright holder for this preprint (which was not certified by peer review) is the author/funder, who has granted bioRxiv a license to display the preprint in perpetuity. It is made available under aCC-BY-NC-ND 4.0 International license.

506 The authors declare no competing financial interests.

507
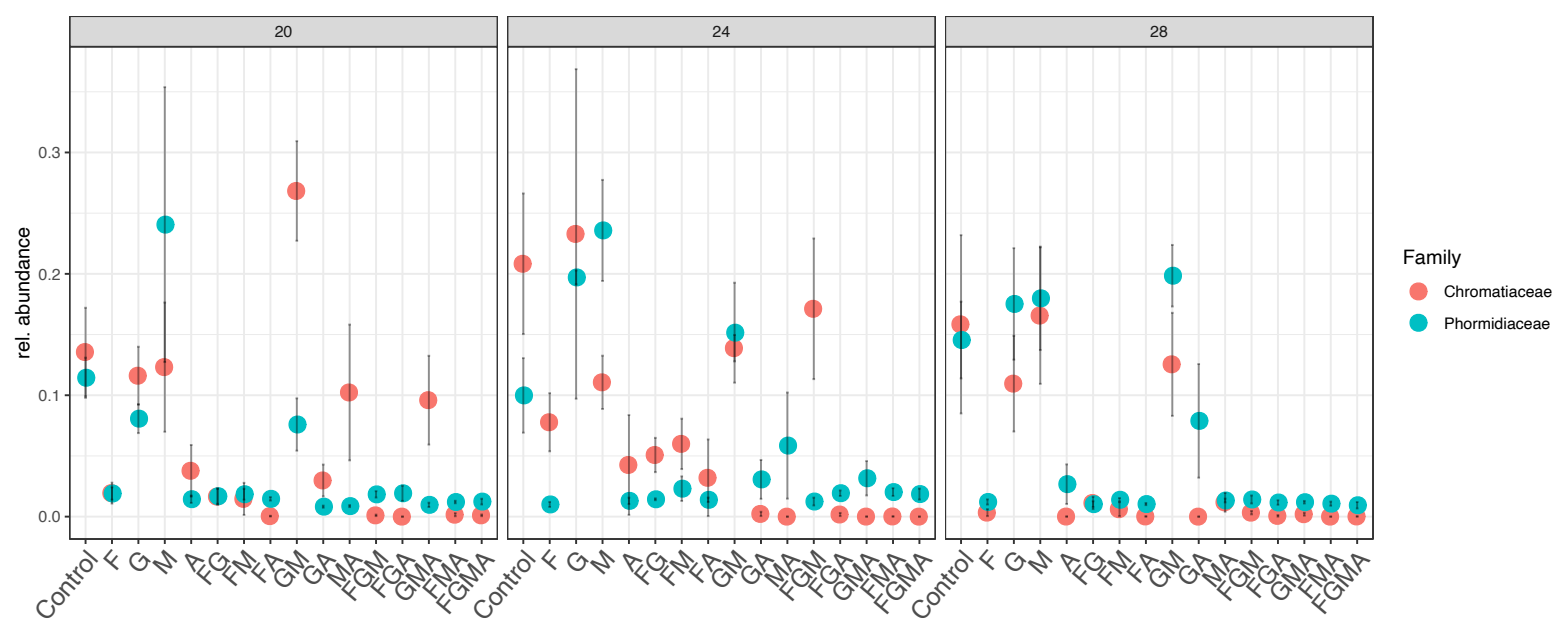

Stressor combination

Supplementary Fig. 1 Relative abundance of Chromatiaceae and Phormidiaceae in the micro-ecosystem depending on stressor combination and temperature. Mean is shown by the circle, standard errors are shown, $n=5$ )

512

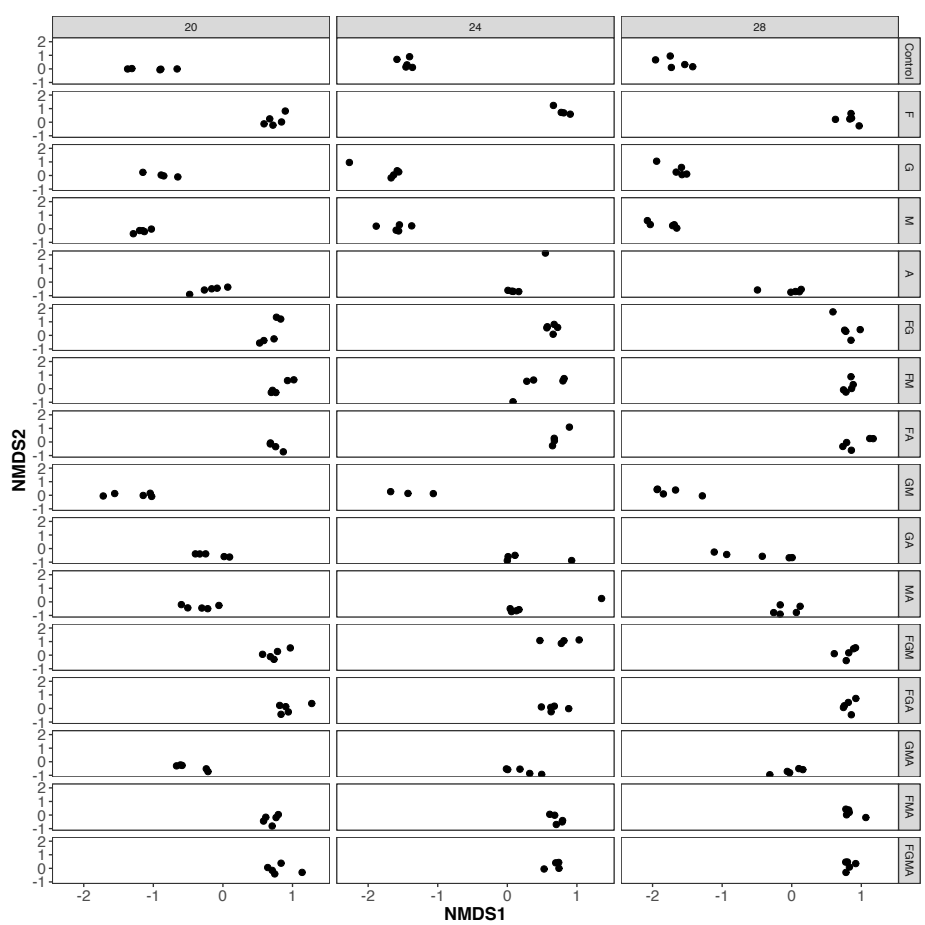

Supplementary Fig. 2 Beta-diversity based on NMDS analysis (Bray-Curtis) in relation to temperature and stressor 
bioRxiv preprint doi: https://doi.org/10.1101/2021.12.13.472339; this version posted December 22, 2021. The copyright holder for this preprint (which was not certified by peer review) is the author/funder, who has granted bioRxiv a license to display the preprint in perpetuity. It is made available under aCC-BY-NC-ND 4.0 International license.
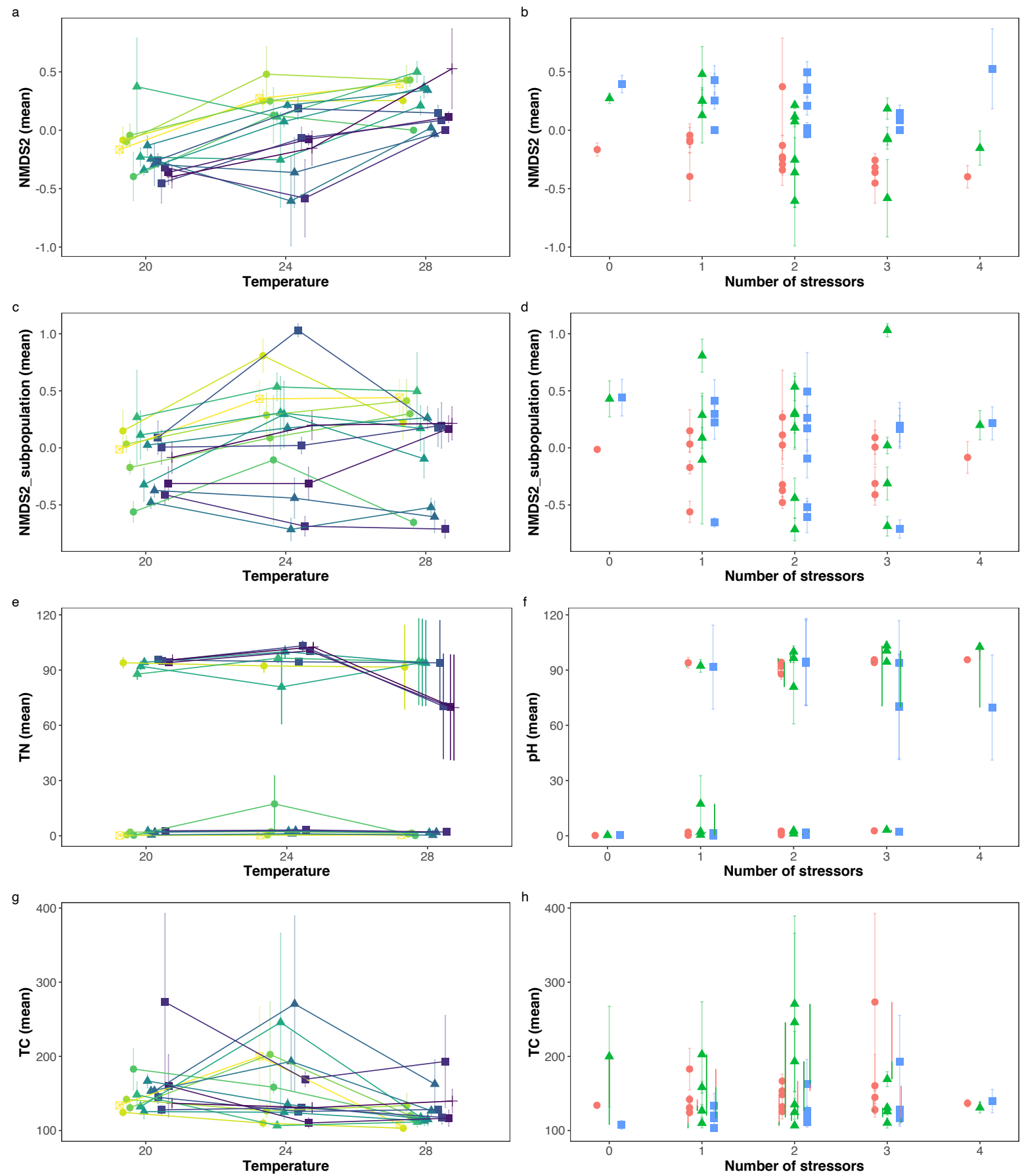

- 1_stressor A 2_stressor - 3_stressor + 4_stressor $\otimes$ control

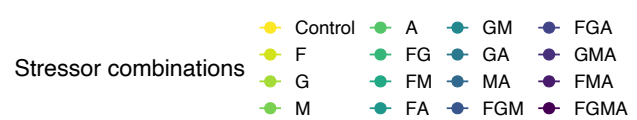

Temperature $-20 \div 24 \div 28$

Supplementary Fig. 3 Effects of stressor combination and number of stressors on temperature applied for microbial community and ecosystem variables. NMDS2 scores in dependence on (a) temperature and stressor combination and (b) temperature and number of stressors. NMDS2_subpopulation scores in dependence on (c) temperature and stressor combination and (d) temperature and number of stressors. Total nitrogen concentration in dependence on (e) temperature and stressor combination and (f) temperature and number of stressors. Total carbon concentration in dependence on (g) temperature and stressor combination and $(h)$ temperature and number of stressors. Standard errors are shown $(n=5$ replicates). 